\title{
KÄYKÖ VAPAA SIVISTYSTYÖ KAUPAKSI?
}

\author{
Puheenvuoron käyttäjä Hannele Koivunen on Vantaan kaupungin \\ kirjastotoimenjohtaja. Hänen näkökulmansa vapaan sivistystyön \\ houkuttelevuuteen ja tarpeellisuuteen on hänen oma työkenttänsä, \\ kirjasto. Hänen jälkeensä samaa kysymystä käsittelee koulutuspäällikkö \\ Risto Seppänen Jyväskylän yliopiston täydennyskoulutuskeskuksesta \\ näkökulmanaan kansalais- ja työväenopistot sekä kansanopistot. \\ Molemmat puheenvuorot on pidetty Yleisradion samannimisessä \\ sarjassa tammikuussa.
}

Vapaan sivistystyön käsite on sanakummajainen, jolla on kytketty yhteen vuosisadan alun kansanvalistuksen aatteen siivittämänä syntyneet toimintamuodot: kansanopistot, opintokerhotoiminta, kansalais- ja työväenopistot sekä yleiset kirjastot.

Vapaata nämä toimintamuodot ovat vapaaehtoisuudessaan sekä erotukseksi oppivelvollisuuskoulutuksesta ja ammattillisesta koulutuksesta.

Kansanvalistusaate uskoi yleissivistävien opintojen tärkeyteen kansakunnan henkisten ja aineellisten olojen kohentajana ja elämän laadun parantajana. Välitön taloudellinen tai ammatillinen hyöty ei ollut määräävä, vaan oppimista pidettiin itseään palkitsevana humanistisena, ihmisen jalostumiseen johtavana arvona sinänsä.

Lienee omalle ajallemme tyypillinen paradoksi kysyä taloudelliseen hyötyyn viittaavin termein: käykö vapaa sivistystyö kaupaksi? Miten voivat yleissivistyksen markkinat? Riittääkö myyjiä, entä ostajia? Ovatko jotkut sivistystyön muodot romahtaneet pörssissä?

Yleisten kirjastojen kehitys osoittaa, että vapaan sivistystyön eri sektoreista se lienee ollut ekspansiivisin ja kansalais- ja työväenopistojen ohella se on parhaiten pitänyt pin- määrällisesti mitattavaan tulokseen: lainausja käyttölukuihin, kysyntään ja tarpeisiin.

Vuonna 1988 maamme yleisistä kirjastoista lainattiin yli 86 miljoonaa teosta eli keskimäärin 17,5 kappaletta jokaista suomalaista kohti. Rahalla mitaten yhden lainan kustannuksiksi on saatu kymmenen markkaa eli kirjalaina on kulttuuripalveluista edullisin.

Lainaustoiminta on kuitenkin vain osa kirjaston tarjoamista palveluista. Kirjastossa voi myös lukea lehtiä tai tutkia käsikirjaston antia, saada neuvoja ja tietopalveluja eri aiheista joko manuaalisesti hakuteoksista tai atk-pohjaisesti eri tiedostoista. Useissa kirjastoissa voi lainata ja kuunnella äänitteitä. Uusina aineistoryhminä kirjastoihin tekevät tuloaan tietokoneohjelmat ja videokasetit. Lapsille järjestetään satutunteja, koululaisille kirjastokäyntejä. Monissa, etenkin pienissä kunnissa, kirjasto on kulttuurin solmukohta näyttelyineen ja tilaisuuksineen. Ja tietysti kirjasto on se paikka, jonne aina voi mennä ilman mitään erityistä syytä. Se on koko kansakunnan yhteinen olohuone, jossa eri yhteiskuntaryhmistä tulevat kohtaavat joskus kiusallisestikin, kun meluisa nuoriso valtaa kirjaston tai rappioalkoholisti etsii sieltä lämpöä.

Kirjaston julkista menestymistä on viime vuosina korostettu myös kirjastorakentamisella: monet uudet kirjastot ovat "tiedon temppeleitä", joiden tilakäsitys ja muotokie- 
li muistuttavat erehdyttävästi taivaallisen ja maallisen vallan edustusrakennuksia: kirkkoja ja pankkisaleja. Mahtipontistaen rakennusten kautta voi välittyä kuva uskon, rahan ja tiedon instituutioiden jäykkyydestä.

Toki kirjastoarkkitehtuurissa on nähtävissä toinenkin, ihmisten lähelle pyrkivä, yhteyttä ja tietoverkostoa infrastruktuurina korostava juonne.

Kirjasto tavoittaa kuntalaiset muihin kunnallisiin palveluihin verrattuna erittäin hyvin. Kirjaston verkko ja palvelut tulevat lähelle. Kirjastoauto kulkee siellä, mistä myymäläauto on jo kuollut. Aukioloajat poikkeavat virka-ajoista, joskin palvelun kohdentamisessa ihmisten vapaa-aikaan, esimerkiksi viikonlopuksi on vielä kehittämistä. Erään tutkimuksen mukaan kirjaston palvelut ulottuvat yli 80 prosenttiin kotitalouksista ja kirjaston palvelukyky ja palvelualttius koetaan positiivisiksi.

Ovatko kirjaston asiakkaat sitten niin tottuneita oman kirjastolaitoksemme yleispositiivisuuteen ja yleishyödylliseen mukavaan ilmeeseen, ettei kritisoitavaa löydy tai sitä ei hahmoteta? Osaavatko asiakkaat asettaa kysymyksen siitä, millä tavalla toisenlainen kirjasto voisi olla? Olemmeko me kirjastossa työskentelevät ikään kuin liian sisällä omissa vanhoissa ammattikäytänössämme havaitaksemme niitä muuttuvan ympäristömme elementtejä, joihin kirjaston pitäisi reagoida? Osaammeko me vastata asiakkaiden muuttuviin tarpeisiin vai menetämmekö jonkun kohderyhmän tarjoamalla vanhentuneita tuotteita?

Kirjaston tehtävän ja yhteiskunnallisen roolin muutokset ovat niin hitaita prosesseja, ettei niitä ole helppoa havaita. Vasta pitkän aikavälin tarkastelu tuo esiin selviä muutoksia. Vuosisadan alusta aina 1950-luvulle saakka oli vallalla kansaa valistava, huolellisesti valittua, 'hyvää' kirjallisuutta tarjoava tehtävä. 60-luvulla ikkunoiden avautuessa muuhun maailmaan ja sodanjälkeisten tuntojen hellittäessä, myös kirjastoihin ylsi uusien medioitten viesti ja massaviihteen aikakausi. Aiemmin kirjaston antina arveluttavana pidetystä viihteestä tuli kokoelmien luontainen osa. 70-luvun yhteiskunnallinen paatos korosti sosiaalista kirjastotyötä, vammaisten ja vähemmistöjen palvelua. 80-luvulla iskusanaksi nousi oikeus tietoon ja tietopalvelun tehostuessa atk:n myötä uskottiin, ehkä valistuksen ajan tapaan vähän nai- vistikin ihmiskunnan tulevan onnelliseksi tehokkaan tiedon löytymisen avulla.

Kirjasto on kuitenkin edelleen sitä, mitä se oli savitaulujen ja pergamenttien aikaan: ihmiskunnan muisti, kollektiivinen tajunta, mahdollisuus liikkua ajassa menneisyyden ja tulevaisuuden, yliminän ja alitajunnan välillä, hallitsevien ja hallittujen välillä, miesten ja naisten välillä. Kirjasto säilyttää esiin poimittavaksi asiat ja niiden vastakohdat. Kirjaston kautta voi peilata toisen tajuntaa omaan tajuntaansa, toisen elämystä omana elämykseensä. Eräässä runossa, jonka on muistaakseni kirjoittanut Lassi Sinkkonen, tämä kuvataan osuvasti: On luettava vanhoja kirjoja tietääkseen, mikö uusissa on uutta. On luettava uusia kirjoja tietääkseen, mikä vanhoissa on totta.

Kirjasto on myös ainoa paikka, missä ihminen voi itse etsiä vastausta juuri omaan kysymykseensä. Kaikki muut palvelut ja tieto annetaan valmiina jonkun auktoriteetin kautta. Koululaitos ja joukkoviestimet kaatavat päälleemme valmiin kuvan, jossa me emme voi itse olla kysymässä. Vain kirjasto voi palvella yksilöllisesti etsien vastauksia ihmisten kysymyksiin. Kirjasto on demokraattisen yhteiskunnan ehto.

Kirjastolla on siis ikivanhoja, aina ajankohtaisia tehtäviä, mutta sen toiminta heijastaa myös yhteiskunnallisia muutoksia. Mikä voisi olla kirjaston sosiaalinen tilaus tänään, mitkä meidän haasteemme 1990-luvulla ja uudella vuosituhannella? Onko se pelkästään tehokas ja taloudellinen yhteiskäytön muoto? Onko se valikoitua aineistoa tarjoava sivistyslaitos? Onko se kuntayhteisön kulttuurin kehto? Onko se koululaitoksen ja opiskelun tuki? Onko se nuorelle ja vanhalle se paikka, johon ainakin aina voi mennä?

Kirjasto on kaikkea tätä ja vielä enemmän: kirjastoverkon kautta avautuu mahdollisuus kaukolainoin, kopioin ja telefaksein saada käsiin ihmiskunnan henkinen pääoma. Unescon UAP (Universal Availability of Publications) -ohjelman periaatteena, jota kirjastot toteuttavat, on saattaa kaikki maailmassa julkaistu materiaali kaikkien saataville. Tämän tehtävän tärkeys on entisestään korostunut maailmassa tapahtuvien nopeiden mullistusten, kansojen ja valtioiden keskinäisen riippuvuuden myötä. Liitymme pian euroyhteisöön ja siinä, missä ennen oli kylä, on tänään koko maapallo. Globaali riippuvuus edellyttää globaalia ymmärtämistä ja globaali ymmärtäminen edellyttää tiedon saantia. Kaaoksen ja järjestyksen ymmärtä- 
minen edellyttää tietoa. Kuka olisi voinut ennustaa muutama vuosi sitten, että maailmaa järisyttäneiden kumousten ymmärtäminen edellyttää enemmin kulttuuriantropologian tai uskontotieteen kuin talous- tai yhteiskuntatieteen käsitteistöä ja tutkimusotetta. Kirjasto säilyttää käyttöä varten myös epämuodikasta vanhaa aineistoa, joka voi yhtäkkiä tulla mitä ajankohtaisimmaksi.

Yhteisömme nopeaa muutosta vastaa koululaitoksen, ammatillisen koulutuksen ja myös vapaan sivistystyön kriisi. Menetelmät on punnittava uudelleen elinikäisen koulutuksen ja elämänkaareen mahtuvien monien ammatinvaihdosten maailmassa.

Tärkeimmäksi tulee kyky sopeutua nopeasti, hankkia tietoa nopeasti. Koulutuksessa korostuvat ongelmakeskeinen opetus ja omaehtoinen tiedonhaku. Tämä ei ole mahdollista ilman kirjastoa. Kirjaston on yhä paremmin ja yhä enemmän kytkeydyttävä palvelemaan koulutusta sen kaikissa muodoissa. Tähän sillä on joustavan palveluluonteensa vuoksi hyvät mahdollisuudet.

Kirjaston suureksi tehtäväksi ja painotukseksi 1990-luvulla ja ensi vuosituhannella nousee vuorovaikutus oman palveltavan lähiyhteisön, oman maan ja kansan, maailman ja kansojen välillä. Kirjaston edustama vapaan sivistystyön sektori käy kaupaksi vain, jos se voi vastata asiakkaiden, kuntalaisten ja kansalaisten kysymyksiin. Kirjaston pitää kehittyä kunnan tietokeskukseksi, tietojen ja elämysten resurssikeskukseksi, joka palvelee kuntalaisia, hallintoa ja elinkeinoelämää. Kirjasto on kunnassa sähkölaitoksen tai vesijohtolaitoksen kaltainen tietoliikenneverkko, hermosto, jossa tiedon ja elämysten impulssit virtaavat käyttäjilleen.

Kirjaston kehittäminen yhä paremmin palvelevaksi ei käy ongelmitta ja jännitteittä. Maailmassa, missä historiaa kirjoitetaan yhä uudelleen, kirjasto on monissa maissa, muun muassa tämän päivän Yhdysvalloissa ja Englannissa sekä totalitaarisissa valtioissa joutunut voimakkaidenkin sensuuritoimenpiteiden kohteeksi. Kuntien itsehallinnon lisääminen ja yleisen, yhteisen kirjastoverkon kehittäminen voivat joutua ristiriitoihin.

Palaan jälleen otsikkoni kysymykseen: käykö vapaa sivistystyö kaupaksi? Liian lyhyen tähtäyksen taloudellisuus kirjastoa koskevassa päätöksenteossa voi käydä hyvin kalliiksi. Tähän liittyy monia käytännöllisiä ongelmia. Kirjastojen maksullisuus, valtion-

osuuksien vähentäminen ja aineiston tekijä- noikeudet ovat keskustelunalaisia kysymyksiä, jotka voivat johtaa kirjaston toimintaperiaatteiden vastaisiin käytäntöihin siinä missä sensuurikin.

On vaikeaa nähdä rationaaliseksi toiminnaksi esimerkiksi atk-pohjaisen tiedonhaun maksullisuutta, jos tällä korvataan aiempia kalliimpia paperimuotoisia aineistoja, joita asiakas saisi edelleen ilmaiseksi. Tuloksena voi olla uusien aineistotyyppien hankinnan halvauttaminen ja samalla epätaloudellisuus. Tekijät ja taiteilijat tarvitsevat kunnollisen korvauksen työstään, mutta he tarvitsevat myös yleisönsä. Tekijänoikeuksia säädettäessä pitäisi ottaa huomioon kirjaston erityisluonne. Jos nykyinen tekijänoikeuskäytäntö olisi ollut voimassa, Kalevalaa ei olisi koskaan syntynyt, niin raaasti Lönnrot otti ja käsitteli eri runonlaulajien tekstejä.

Ja missä silloin olisi kulttuurimme, Kalevala on käynyt hyvin kaupaksi.

Kirjasto ei käy kaupaksi tavaroilla, vaan asettaa ihmisten ulottuville detaljeja, faktoja, viisautta ja elämyksiä. Kirjasto on tie, polku, jonka varrelta voi löytää sitäkin, mitä ei etsi eli Umberto Econ sanoja mukaellen kirjasto on veruke, jonka avulla voi törmätä johonkin odottamattomaan ja itselle tärkeään.

Ja vielä lopuksi kaupankäynnistä: jos sinulla on markka ja minulla on markka ja me vaihdamme nämä rahat, on kummallakin edelleen yksi markka. Mutta jos sinulla on ajatus ja minulla on ajatus ja me vaihdamme ne, on kummallakin sen jälkeen kaksi ajatusta.

Kirjasto on täynnä ajatuksia ja ne kaikki ovat sinun käytettävissäsi.

HANNELE KOIVUNEN 